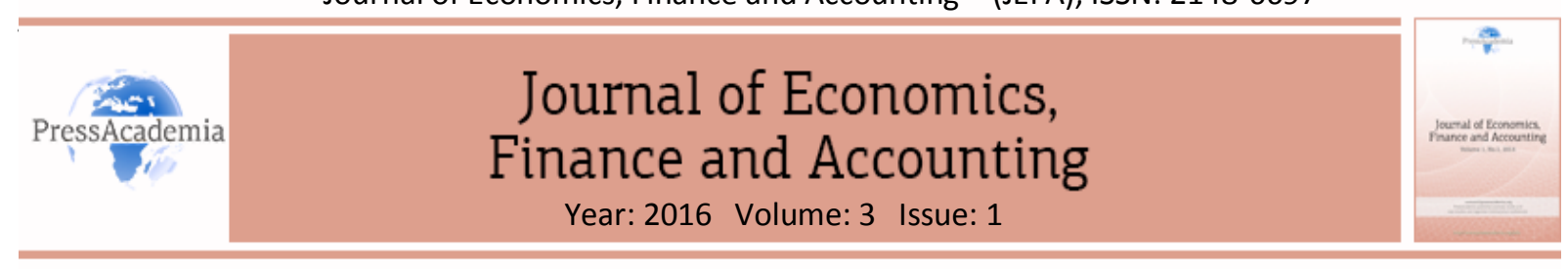

\title{
EVALUATION OF ACCOUNT NUMBER PORTABILITY IMPLEMENTATION IN BANKING SECTOR OF TURKEY
}

DOI: 10.17261/Pressacademia.2016116533

\section{Cuneyt Dirican'}

'Istanbul Arel University. cuneytdirican@arel.edu.tr

\begin{abstract}
Is it possible to implement bank account number portability in banking industry just like telecommunication and pension system examples? In a mobile world where the customer behaviors and demands are changing rapidly, the idea of account number portability in banking industry, comparing with the aggressive competition in telco and pension industries, must be discussed as well. Account number portability in banking will have a huge impact on many business headlines. Risk management, money laundering, fraud, loans, cards, automated bill payments, deposit insurance, clearing and switching mechanism and its governance, competition law and capital accord should be examined. Within this conceptual and hypothetical study, the fundamental principles and requirements as well as countries case studies are highlighted and account number portability in Turkey is discussed. The basic and critical needs are proposed for account number portability in order to be a guideline for academic works and professional initiatives in the banking industry, in the future.
\end{abstract}

Keywords: Bank account number portability, customer experience, bank account switching, mobile financial services, operational efficiency.

JEL Classification: G20,G21,G23

\section{HESAP NUMARASI TAŞINABiLIRLIĞINNIN, BANKACILIKTA VE TÜRKIYE'DE UYGULANABiLIRLIĞiNIN DEĞERLENDIRILMESi}

\section{ÖZET}

Tüketicilerin, telekom ve bireysel emeklilik sektöründe deneyimledikleri telefon numarası ve sözleşme taşınabilirliği bankacılık sisteminde uygulanabilir mi? Mobil bir dünyada, tüketici davranışları ve tercihleri hızla değişirken, en az finansal hizmetler sektörü kadar yoğun rekabetin yaşandığı telekom ve bireysel emeklilik alanında, Türkiye'de uygulanan telefon ve sözleşme numarası aktarımının / taşınabilirliğinin bankacılıkta uygulanabilirliği, farkıı açılardan değerlendirilmesi ve tartışıması gereken bir konu başlığıdır. Hesap numarası taşınabilirliğinin müşteri deneyimi, risk yönetimi, kara para aklama, suistimal, sahtecilik, krediler, kartlar, fatura ödeme, karşılıklar, mevduat sigorta primi, takas yöntemi ve yeri, rekabet kanunu gibi bir çok başıkta incelenmesi gerekmektedir. Bu çalışmada, dünyadaki limitli uygulamalar ışı̆ıında, Türkiye'de uygulanmasının temel prensipleri, gereksinimleri ilerideki akademik ve sektördeki profesyonel çalışmalara rehberlik etmesi açısından, kavramsal olarak tartışıımıs, incelenmiş ve banka hesap taşınabilirliği önerilmiştir.

Anahtar Kelimeler: Banka hesap numarası taşınabilirliği, müşteri deneyimi, banka hesabı aktarımı, mobil finansal hizmetler, operasyonel verimlilik.

JEL Sınıflandırması: G20,G21,G23 


\section{GiRiş}

Dünya genelindeki tüm şirketlerde sürdürülebilir karlılık, bankacılık sektöründe ise, özellikle Türkiye'de, sermaye karlılı̆ı ve aktif karlılığı en önemli gündem maddelerinden biri olarak yönetimlerin gündemini meşgul etmektedir. 2008 yılında ABD'de, Lehman Brothers Yatırım Bankası'nın “Global Finansal Kriz" yaratarak batması sonrası başlayan süreç ile beraber, bankacılık sektöründe ve dünyadaki uluslararası firmalar başta olmak üzere tüm şirketlerde bu başlıklar daha da önem kazanmıştır. Keynes'in “Likidite Tuzağı Teorisi” nin (Baydur ve Süslü, 2011) deneyimlenmesine neden olan sıfır seviyelerindeki Merkez Bankaları politika faizi 2008'den bu yana en önemli para politikası aracı olarak kullanılmaktadır. Ancak, Rahman ve Toyoda'nın 2009'da belirttiği gibi “Paranın Yansızığı Teorisi” kapsamında (Tuğcu, 2015; Doğan 2005) dünya ekonomilerinin artan global likiditeye rağmen büyümüyor olması, ülke enflasyon oranlarının alınan tüm para politikaları kararlarına rağmen, global talebin ve büyümenin arttığını teyit edecek beklenti seviyelerine çıkmıyor olması, verimlilik, etkinlik, karlılık başlıklarını şirketler ve ülkeler özelinde daha elzem hale getirmektedir.

Öte yandan, 1990 lardan sonra internetin ve mobil teknolojilerin ticari ve sosyo-kültürel hayata hıla girmesi ile dijitalleşme sürecinin tetiklediği bir tüketim dünyası oluşmaya başlamıştır. Finansal hizmetler sektöründe mobil bankacılık, internet bankacılığı, sosyal medya gibi başlıklar bir anda klasik pazarlama ve hizmet anlayışını değiştirmiştir. Paranın, elektronik devrelerde ve ikilik sayı düzeninde, dijital ekonomi çağı ile beraber yeni ödeme sistemlerinde hızla gelişmesi ve finans kurumu olmayan finansal aracıların piyasalarda aktif rol almaya başlaması, başta bankacılık olmak üzere, finansal hizmetler sektöründeki aracıların, yeni teknolojilere daha hızlı uyum sağlaması gerekliliğini doğurmuştur. Globalleşme, dijitalleşme, CRM ve alternatif dağıtım kanalları alanındaki inovatif çalışmalar dâhilinde, bilgisayarların ve internetin gelişimi ile finansal hizmetler sektörü yeni bir rekabet dönemine girmiştir. Dünyada artan kaydi para arzı, büyümesi yavaşlayan ekonomiler, müşteri taleplerindeki ve beklentilerindeki değişimler, sosyal medya ile iletişim formatlarındaki farklı interaktif etkileşimler ile bilançolarını daha verimli ve sonuç, odaklı yönetmek durumunda kalmaya devam etmektedirler. Yapay zekâ, robotik ve drone'lar gibi teknolojik gelişmeler, büyük veri, bulut teknolojisi, nesnelerin interneti, yapay sinir ağlarda veri madenciliği, giyilebilir elektronikler, hologram, uzay teknolojileri, 3D yazıcılar gibi 4.ncü Sanayi Devrimi olarak nitelenen tüm yenilikçi gelişmeler devletleri, ekonomileri, sektörleri, şirketleri, bankaları, yöneticileri ve çalışanları yakından etkilemeye devam edecektir.

Porter'ın “Değer Yaratma ve Rekabet Avantajı Kuramı” (Porter, 1985) kapsamında yeni gelir imkânları yaratmak ve/veya giderleri minimize etmek ya da küresel rekabette ve uzay yarışında öne geçmek amacı ile giderek ivme kazanan AR-GE faaliyetleri, bankacılıkta farklı gelişmeleri tetikleyebilir mi? Tüketicilerin, telekom ve bireysel emeklilik sektörlerinde deneyimledikleri telefon numarası ve sözleşme taşınabilirliği, bankacılık sisteminde hesap numaralarının taşınabilirliği şeklinde bu ve benzeri nedenler ile denenebilir mi?

Hesap numarasının taşınabilirliği, "portability" veya "switching" olarak yabancı literatürde kelime karşılıklarını bulmuştur ve müşteri talimatına istinaden talimatı alan banka tarafından diğer bankaya emir göndererek hesabı/hesapları kendisine transfer etmesi işlemi olarak tanımlanabilir. Bu taşıma işlemi kısmi veya tam olarak gerçekleştirilebilir. Kısmi taşımada daha çok eski bankadaki hesaptan yeni bankadaki hesaba yönlendirme, tam taşımada ise eski hesabın, hesap numarası dâhil tüm müşteri bilgileri ile yeni bankaya taşınması işlemi kastedilmektedir.

Fransa'da UFC-Que Choisir adlı tüketici derneği, 2012'de regülatörlere bir talep yaparak “Bankacılıkta Hesap Numarası Taşınabilirliği” tartışmasını gündeme getirmiş (cbanque.com, 2012) ve konu Avrupa Birliği'nde yeniden tartışmaya açılmıştır. Bu tartışmalar, EPC (European Payment Council) yani Avrupa Ödemeler Konseyi çalışmaları başlığı altında, 2002 yılındaki kuruluşundan bu yana belirli dönemlerde devam etmektedir. SEPA (Single European Payment Area) yani Tek Avrupa Ödemeler Bölgesi kapsamında, İngiltere, İspanya, Macaristan'da ağırlıklı olarak 2007 ve 2008 yıllarında benzer tartışmalar yapılırken, Avustralya'da konu benzer zaman dilimlerinde hayata geçmek üzere araştırılmaya başlanmıştır. Avrupa Birliği'nin banka hesaplarının taşınması ile ilgili 23 Temmuz 2014 direktifinin (Official Journal of the European Union, EUR-Lex, 2014) kabulü öncesinde, uzman (eskper) grubunun "Banka Hesapları ile ilgili Müşteri Mobilitesi” raporuna yönelik olarak, Alman Deutsche Bank'ın Avrupa Birliği ilgili komisyonuna verdiği cevabında (Speyer ve Schafer, 2007), pazardaki rekabet ve şeffaflık üzerine karşı görüşleri ve ulusal hesap numarası taşınabilirliği üzerine nispeten olumlu 
görüşü bulunmaktadır. Bu konuda 2008 yılında yayımladığı (Deutsche Bank Research, 2008) ayrıca bir detaylı raporu daha bulunmaktadır. Avustralya'da eski Merkez Bankası başkanı Bernie Fraser, Avustralya Hükümeti'nin "Rekabetçi ve Sürdürülebilir Bankacılık Sistemi" için 2010 yılında attığı adım kapsamında konu üzerinde bir rapor hazırlanması için görevlendirilmiştir ve rapor 2011'de sunulmuştur. (Fraser, 2011). Çalışmanın başlangıç noktası, tüketici lehine hükümetin aldığı önlemler kapsamındadır ve bu konuda Türkiye'deki Başbakanlığın ve BDDK'nın Finansal Tüketicinin Korunması çalışmalarına benzemektedir.

Ülkemizde ise banka müşterileri, her finansal ihtiyacını giderme aşamasında, zorunluluklar ve hesap işletim ücreti gibi finansal kaygılar nedeni ile farklı bankalar ile çalışmak durumundadırlar. Kurum çalışanları, maaş ödeme işlemlerinde, şirketlerinin tercihi doğrultusunda kurumsal çalışılan bankadan ücret ödemelerini almak zorunda kalmaktadır. Bu tarz işlemler, müşterilerin üzerinde bir operasyonel külfet olarak devam ederken, aslında sermaye karlılığı (ROE) ve aktif karlılığı (ROA) rasyoları düşmeye devam eden bankacılık sektörünün operasyonel maliyetlerini arttıran bir etkiye sahip olarak karşımıza çıkmaktadır.

Teorik olarak, bankalar arasında banka hesaplarının taşınabilirliği teknolojik, pazarlama ve operasyon gibi ana başlıklar kapsamında mümkün olmakla beraber, konunun Türkiye özelinde ve dünyadaki bankacılığın temel işleyiş ve operasyonel süreçleri çerçevesinde detaylı olarak incelenmesi gerekmektedir. Mevzuat ve yasalar bu anlamda ilk sırada gelmektedir. Rekabet Kanunu, Avrupa Birliği ilgili müktesebatı, Kara Para Aklama ve ilgili mevzuatı, IBAN (International Bank Account Number), Merkez Bankası EFT (Elektronik Fon Transferi) sistemi, çek ve kredi kartı takası, SWIFT (Society Worlwide Interbank Fund Transfer), hangi hesapların taşımaya konu olabileceği, sermaye yeterliliği, zorunlu karşılıklar ve tasarruf mevduatı sigorta primleri, zamanaşımı, bankacılık kanunu ve müşteri bilgilerinin gizliliği, veraset kanunu, otomatik fatura ve maaş ödemeleri, kayıt saklama zorunluluğu, ücret ve komisyonlar, bankacılık hizmet sözleşmeleri, kredi kartı takası, internet bankacılığı ve diğer dağıtım kanalları, ana bankacılık sistemleri, iç kontrol ve risk yönetimi gibi birçok başlıkta konunun değerlendirilmesi gerekmektedir.

Bu kavramsal ve kuramsal çalışma, Türkiye'de konusunda bir ilk olarak, ileride bu alanda yapılabilecek akademik ve profesyonel çalışmalara temel teşkil etmesi açısından, farklı başııklar ışığında, konuya uygulanabilirlik açısından öneriler sunmayı amaçlamaktadır. Takip eden bölümlerde sırası ile, literatür taraması yapılmış, örnek ülke uygulamaları incelenmiştir. Benzerlikleri açısından bireysel emeklilik ve telekom sektörlerindeki mevzuat ve uygulama adımları özetlenmiştir. Yöntem ve tartışması aşamasında, Türkiye'deki bankalar arasındaki işbirliği örnekleri ve olumsuz piyasa uygulamaları üzerinden konunun önemi tartışılmış ve kimin inisiyatifinde ele alınması gerektiği önerilmiştir. Bulgular bölümünde, hangi kritik konuların öncelikle ele alınması ve incelenmesi gerektiği öneri olarak listelenmiştir ve son olarak sonuç bölümünde bir özetle banka hesaplarında numara taşınabilirliğinin Türkiye'de ele alınmasının faydalı olacağı kanaati vurgulanmıştır.

\section{LITERATÜR ANALIZi}

Bankacılıkta hesap numaralarının taşınabilirliği konusu dünya genelinde çok fazla ülkede gündeme gelen bir konu olmamıştır. Avrupa Birliği komisyonlarında görüşülmüş olsa da, Hollanda, İsveç, Fransa, Norveç, İngiltere dışında pratikte diğer birlik ülkelerinde daha az gündeme gelmiştir. Dünyada Avustralya'da uzun süre Hazine Müsteşarlığı nezdinde gündemde kalmıştır. Türkiye'de ise bu konuda hiçbir çalışmaya, bankacılık alanında ne akademik olarak ne de profesyonel olarak rastlanmamıştır. Bankacılıktaki uygulamalara ve örneklere geçmeden önce, Telekom ve Türkiye'deki Bireysel Emeklilik Sistemi'nden örneklere ve mevzuat ile uygulamalara bakılmasının, bankalar arasında hesap taşımanın uygulanabilirliği açısından fikir ve yön vereceği düşünülmektedir.

Başbakanlık Hazine Müsteşarlığı'nın, 9 Kasım 2012 tarihinde 28462 sayı ile Resmi Gazete'de yayımlanan "Bireysel Emeklilik Sistemi Hakkında Yönetmelik" hükümleri kapsamında bir emeklilik şirketinde müşteri tarafından sahip olunan bir sözleşme başka bir emeklilik şirketine kendi talebi veya şirket katkı paylı ise sponsor şirketin talebi ile aktarılabilir. Eğer ilk defa oluşan bir sözleşme ise emeklilik şirketinde fon ve sözleşmenin 2 sene, eğer aktarıma konu olmuş bir sözleşme ise en az 1 sene ilgili emeklilik şirketinde kalmış olması şekil şartı bulunmaktadır. Süreç olarak ise, müşteri talebine istinaden 5 gün içinde aktarım ile ilgili dokümanların eski şirket tarafından müşteriye iletilmesi ve talebin kendisine ulaşmasından itibaren 10 gün içinde aktarım 
sağlanarak, 2 gün içinde de Emeklilik Gözetim Merkezine bilgisi ulaştırılmalıdır. Bu süreçte varsa Devlet Katkı Payı ile birikimlerin tamamı aktarılır.

Türkiye'de, Bilgi Teknolojileri ve İletişim Kurumu (BTK) bünyesinde kurulmuş olan "Numara Taşınabilirliği Sistemi (NTS)" 9 Kasım 2008 tarihinde hayata geçmiştir. Uygulamada, operatörlerin müşterileri tarafından yapılan numara aktarma/taşıma talepleri GSM operatörleri tarafından NTS'ye iletilmekte ve ilgili güncel mevzuat çerçevesinde gerekli taşıma ve çalıştırma işlemleri yapılmaktadır. Sabit telefon hatlarında ise numara taşınabilirliği 10 Eylül 2009 tarihi itibariyle hayata geçmiştir. Sistemin hayata geçtiği günden bu çalışmanın tarihine kadar geçen dönemde 90 milyona yakın mobil hat numarası, 1 milyon adede yakın olarak da sabit telefon hattı numarası taşımaya konu olmuştur. (BTK, nts.gov.tr, 2016). Son BTK raporu ise (Bloomberght, 2015), mobil numara taşımanın yavaşladığını ve sabit telefonlarda numara taşımanın fazla tercih edilmediğini göstermektedir.

Telekom sektöründe ilgili mevzuat kapsamında “Numara Taşınabilirliği Yönetmeliği (Yönetmelik)”, 01/02/2007 tarih ve 26421 sayılı Resmi Gazete'de yayımlanmış ve sonrasında yürürlüğe girmiştir. Tanım olarak numara taşınabilirliği ise, operatörlerin abonelerinin telefon numaralarını değiştirmeye gerek kalmaksızın, karşı operatöre verdiği talimata istinaden, telekom hizmetleri aldığı mevcut operatörünü ve aldığı hizmetin türünü değiştirebilmesi anlamına gelmektedir. Bu işlemlerin yapılabilmesi içinse, operatörler arasında "Merkezi Referans Veri Tabanı (MRVT)" adı ile taşınmış numaralar, bu numaralara ilişkin yönlendirme ve operatör bilgileri ile diğer ilgili bilgilerin tutulduğu ortak bir referans veri tabanı oluşturulmuştur. Abone taşıma işlemleri ise özetle aşağıdaki prensipler çerçevesinde yapılmaktadır.

- Numara taşıma işleminin başlayabilmesi için hat sahibi abonenin yeni abonesi olmak istediği operatöre başvurması gerekir.

- Abonenin başvurusunda, taşınacak hat numarası, kimliğini ispatlayıc kimlik bilgileri, mevcut operatör bilgisi, tercih ettiği taşıma zamanı ve abonesi olmak istediği yeni operatör bilgileri bulunur ve yeni operatör ile numara taşıma gerçekleştikten sonra geçerli olacak yeni abonelik sözleşmesini imzalar.

- Talebi alan yeni operatör eski operatöre gönderilmek üzere, bilgileri en geç 2 gün içerisinde, MRVT'ye gönderir. Bilgiler doğru ise, eski operatör 2 gün içerisinde taşıma işlemine onay verir ve onaydan itibaren 48 saat içinde numara taşıması gerçekleşir. Eğer yönetmelikte yer alan sebeplerle (telefon numarasının başkasına ait olması, kendi operatöründen değişiklik talep etmesi, bilgilerin yanlış olması, daha önce yapılmış ve süreci devam eden başka bir taşıma talebi olması gibi) talep ret oluyorsa yine 2 gün içerisinde bunu karşı tarafa bildirir.

- Onay sonrasında, MRVT taşınacak telefon hattının numarasını ve taşıma zamanını çağrı başlatan tüm operatörlere bildirir. Numaranın fiilen taşınacağı tarih ve saat ise, yeni operatör tarafından hat sahibine bildirilir. İlgili tarih ve saatte eski operatör sisteminde numaranın aktivasyonunu kapatır ve MRVT üzerinden bu karşı operatöre ulaştığında yeni operatör kendi sisteminde numarayı aktive eder.

- Telefon hattına dair numaranın taşıma işlemi, abonenin talebinden itibaren en fazla 6 gün içerisinde tamamlanır.

Mobil telefon numaralarının taşınabilirliğinin müşteri kazanımı, pazar fiyatları ve rekabet üzerine araştırmasının (Cho, Ferreira ve Telang, 2013) bulgularına göre, 15 Avrupa ülkesindeki 47 mobil operatör arasında 1999 ile 2006 yılları arası ampirik olarak incelenmiş ve uygulamanın fiyatları \%7.9 oranında düşürdüğü, talep fiyat elastikiyeti ölçümleri sonucunda müşterilerin kişi başına 2.86 Euro ek kazanımı olduğu ve numara taşımanın bu anlamda rekabet açısından iyi sonuçlar verdiği ortaya konulmuştur.

Telekom sektöründe numara taşınabilirliği ile ilgili Türkiye'de yapılan bir pazar araştırması raporunda (Güngör ve Evren, 2010) yer alan bulgular ise, bu anlamda bankacılık sektöründeki hesap numarası taşınabilirliği açısından da önemli fikirler verecektir.

Telekom sektöründe numara taşınabilirliği dünyada ilk kez Singapur'da devreye alınmış, Avrupa Birliği'ndeki ilk uygulama 1999 yılında mobil numara taşınabilirliği ile İngiltere'de olmuştur. 2002 yılında, Evrensel Hizmet Direktifinin 30. Maddesi ile birliğe üye ülkelerde mobil hizmetler dâhil kamu hizmetlerinden yararlanan tüm 
abonelere numaralarını değiştirme hakkının sağlanması yükümlüğü getirilmiştir. Numara taşınabilirliği uygulamasının temelde dört olumlu etkisi bulunmaktadır. Numara değiştirme maliyetlerinin azalması, artan rekabet nedeniyle tüketici lehine fayda sağlanması, erişim maliyetlerine katlanmadan hizmete erişebilme ve tüketicinin numaraya yönelik haklarının artması ile artan faydadır. Numara taşınabilirliği kullanıcı bağımlılı̆ı ve değiştirme maliyetlerini azaltıcı etkisiyle ilgili piyasada rekabeti artırıcı bir sonuç doğurmaktadır.

Her ne kadar Türkiye özelinde ilgili rapora göre araştırma sonuçları hakim operatörün pazar kaybı, operatörlerin reklam ve promosyon bütçelerinde artış, abone kayıp (churn) oranlarında yükselme, tarife kampanyalarında müşteri lehine ücretsiz kullanım ile çeşitlilik, taşıma imkanı nedeni ile diğer hatların iptali gibi, operatörler açısından maliyet doğurucu veya olumsuz görünen sonuçlar doğurmuş olsa da, numara taşınabilirliğinde esas kazanımın tüketici memnuniyetinin artıılması, şeffafıı, sürdürülebilirlik olması temel amaç ve beklentidir. Bankacılık açısından konu değerlendirildiğinde, ücret, komisyonlar, hesap açma operasyonel maliyetleri gibi unsurlar dikkate alındığında, benzer beklentiler dâhilinde konunun öncelikle ele alınması beklenmelidir. Nitekim Başbakanlığın 5 Haziran 2014 tarihli "Finansal Erişim, Finansal Eğitim ve Finansal Tüketicinin Korunması Stratejisi ve Eylem Planları Konulu Başbakanlık Genelgesi” bu beklentileri teyit edecek şekildedir.

Bankacılıkta ise, hesap numarası taşınabilirliği üzerine yapılan literatür çalışmasında limitli sayıda ülkede yapılan çalışmalar bulunmaktadır.

Fransa parlamentosunda 2014 yılında yapılan görüşmeler öncesinde, tüketici haklarına yönelik çalışmalar yapan UFC Que Choisir Derneği'nin yayınladığı rapora göre (Quechoisir.com, 2014) bankalarından memnun olmayan müşterilerin oranı \%25 iken sadece \%3'lük bir kesim başka bankada hesap açıp çalışmaya başlamıştır. Senede 2 kere bankalarına uğrarlarken, bu Fransa'da telekom ve sigortacılıktaki oranın $1 / 5^{\prime}$ i, $A B$ ortalamasının $1 / 3^{\prime}$ ü seviyesinde kalmıştır. Bu rapora göre, yıllık \%12,12 değişim oranı ile İspanya en çok banka hesabı değişikliğinin, Yunanistan ise \%2,36 ile en düşük değişikliğin yaşandığı ülkelerdir. Finlandiya ise 17,44 yıl ile en uzun banka hesap ilişkisinin yaşandığı ülkedir. Tek para birimi Euro'ya geçiş sonrası, paranın basım, dolaşım maliyetlerini en aza indirgemek üzere, SEPA kapsamında IBAN (International Bank Account Number) Uluslararası Banka Hesap Numarası uygulaması hayata geçmiştir. Ortada tek para birimi var ise, her ülkede farklı elektronik fon transferi ve takas sisteminin olmasının Avro'nun dolaşım maliyetlerinde bir kazanım sağlamadığı fark edilince, parasal birliğin bütünleşmesini kolaylaştırmak üzere bu çalışmalar hızlanarak devam etmiştir. Tüm Avrupa'da bankalarda yeknesak, standardize edilmiş 26 haneli banka hesap numaraları ile "IBAN No" tüketici ve kurumların ve bireylerin günlük hayatına girmiştir.

Aynı rapora göre (Que Choisir, 2014), 2013 yılında Fransa'da Bain Consulting danışmanlık firması tarafından yayımlanan "Customer Loyalty in Retail Banking 2013" araştırma raporuna göre, 15 bankanın yaklaşık 10.000 müşterisi ile yapılan araştırmada, Fransız bankaları araştırmaya konu 26 ülke arasında Net Promoter Score'u (NPS) en düşük ülke olarak çıkmıştır. Raporda, SEPA'dan gelen IBAN banka hesap kodları ile Avrupa ve Fransa genelinde, hesap numaralarında bir standartizasyon oluşması nedeni ile hesap numaralarının taşınabilirliğinin teknik olarak mümkün olduğu belirtilmiştir ki, Türkiye'de IBAN standardına geçmesi nedeni ile bu imkâna sahip olacaktır. Que Choisir'in raporunda ayrıca, numara taşınabilirliğinin mümkün olmasına rağmen önündeki olası engeller şu şekilde sıralanmıştır:

- Hizmetle ilgili bilgiye ulaşma maliyeti

- Hizmeti terk etme, hesap kapama, taşıma maliyeti

- Prosedürün zorluğu ve uzunluğu maliyeti

- Yeni bankanın uygulamalarına alışma zorluğu

- Yeni bankada hizmet seviyesinden memnun olmama olasılığı

Her ne kadar $A B$ direktifi ile banka hesap numarası taşınabilirliği kabul edilmiş olsa ve Fransa'da ve Avustralya'da gündemi yoğun olarak meşgul etse de, uygulamada işlerlik kazanmış olan dünyadaki ilk başarılı örnek ülke olarak İsveç "The Bank Giro" Sistemi olarak görünmektedir. Onu eski hesaptan yeni hesaba paraları 13 ay boyunca otomatik yönlendiren Norveç'teki "Overstapservice" hesap taşıma sistemi takip etmektedir. (Consumer International, 2012) 2015 yılı Nisan ayında, Fransa'da Senato'nun 1560 sayılı düzenlemesi ile kısmi hesap taşınabilirliği kabul edilmiştir. Kısmi hesap taşınabilirliği, müşterinin yeni bankasına verdiği talimata 
istinaden, eski bankasından paraların ve bu hesaba gelen transferlerin, yeni hesabına otomatik olarak transfer edilmesi (yönlendirmesi) anlamına gelmektedir.(Le Figaro, 2015)

Avrupa Tüketici Organizasyonunun 2012'de yayınlandığı rapora göre (BEUC, 2012), hesap numarası taşınabilirliği üye ülkelerde zorunlu tutulmuş olmasına rağmen, işlerlik kazanmakta zorlanılmıştır. Bunun sebepleri arasında ise, yapılmaması halinde uygulanacak cezaların belirsizliği, tüketicilerin tam ve birebir hesap taşıma olmaması halinde, eski ve yeni hesapları arasında paraların taşınmayacağı korkusu ve direktifin sadece ulusal bazda hesap taşımayı öngördüğü, Euro ve SEPA'ya rağmen sınır ötesi hesap taşımalarının belirsizliği gibi sebepleri göstermiştir.

Deutsche Bank Reserch'ün 2008 tarihli raporunda banka hesap numarası taşınabilirliği üzerine birçok başık detaylı olarak incelenmiştir. Avrupa Birliği komisyonun özellikle rekabetin yeterli olmadığı, tüketicilerin şeffaf bir hizmet anlayışı ile karşılaşamadığı, fiyat ve hizmetler ile ilgili olarak tüketiciler arasında asimetrik enformasyon bulunduğu, sektörde sürdürülebilirlik açısından bu anlamda risklerin bulunduğu şeklinde görüşlerine cevaben rapor farklı savları ele almıştır. Öncelikle, perakende bankacılıkta rekabetin yüksek olduğu, ulusal taşınabilirlik ve sınır ötesi üye ülkeler arasında taşınabilirlik şeklinde iki farklı taşıma durumunun bulunduğu ve konunun bu şekilde iki farkı başıkta ele alınması gerekliliği belirtilmiştir. Ancak, ileride (kastedilen IBAN ve takas/EFT sistemlerinin günümüzde olduğu gibi birleşmesi durumudur) bu iki sistemin birleşmesi gerekliliği ve bu anlamda "bir ölçü hepsini kapsar" anlayışının doğru olmayacağı, bunlardan hareketle farklı mevzuat başlıklarının düzenlenmesi gerekliliği, üye ülkeler bazında müşteri sadakatinin genelde yüksek olduğu ve taşımanın ülke bazında değerlendirilmesi gerektiği aktarılmıştır. Yine, müşterilerin bilgilendirilmesinde bir sorun bulunmadığı, esas ürünler bazında değil, ürün paketlerinde (örneğin, çek, kredi kartı, otomatik ödemenin birlikte sunulması) şeffaflık olamayabileceği, dolayısı ile vadesiz hesapların bu anlamda esas sorun olarak görülemeyeceği ifade edilmiştir. Hollanda'da hesap taşınabilirliği olmasına rağmen çok az sayıda aktarım işlemi yapıldığını, çok daha önemli olarak IBAN ve SWIFT BIC standartlarının yeni hesap standartları ile yer değiştirmesinin gerekeceği ve Know Your Customer (KYC) ile kara para aklama gibi başlıklar nedeni ile operasyonel risklerin bulunduğu raporda örnekleri ile beraber aktarılmışıı.

Mart 2015'de Ingiltere'de yayımlanan rapora göre (Moorhouse Consulting, 2015), 5 farklı iş modeli ile bankalarda hesap numaralarının taşınabilirliğinin mümkün olduğu görülmektedir. 2013 yılında devreye alınan "Current Account Switch Service" kapsamında, İsveç örneği gibi 12 ay boyunca hesaba gelen para hareketlerinin yeni hesaba yönlendirilmesi öngörülmektedir. Özellikle, KYC noktasında merkezi bir veri tabanında banka hesap bilgilerinin tutulması gereksinimi, Türkiye'deki Kredi Kayıt Bürosu'ndaki Findeks kapsamlı kredi bilgilerinin ve skorlarının ortak havuzda tutulması örneğini akla getirmektedir.

Son olarak, banka hesap numarası taşınabilirliği üzerine en kapsamlı çalışmalardan birisi Avustralya'da yapılmıştır. Avustralya'da tam hesap taşınabilirliği üzerine Hazine'nin yaptırdığı araştırma çalışmasına göre (Australian Government Treasury, 2012) merkezi bir veri tabanı üzerinden bu işlemlerin gerçekleştirilmesi gerekmekte, ingiltere, Hollanda, İsveç örnekleri üzerinden bunun çok maliyetli olacağı görüşü öne çıkmaktadır. Bu kapsamda, son gelişme olarak, önerinin bankalarca ret edildiği kaynak taramasında karşımıza çıkmaktadır. (Eyers, 2015)

\section{YÖNTEM VE TARTIŞMA}

Numara taşınabilirliğinin hayata geçirilebilmesi açııından farklı yaklaşım olasılıkları bulunmaktadır. Regülatör kurumların bu konuda inisiyatif alması veya almaması durumuna göre farklı sonuçlar ortaya çıkabilmektedir. İnisiyatif alınmayarak kamu otoritelerince bir düzenleme yapılmaması durumunda, telekom operatörü değiştirme maliyetlerinin ortaya çıkması ve yüksekliği durumu, tarife, ücret ve komisyonların yüksekliği ve tüketicilerin bunlarda mecbur kalması olasılığı, tüketici lehine diğer faydaların azalması genel olarak rastlanılan ana başıklardır. Operatörlerin kendi inisiyatifine konunun bırakılması durumunda ise, aralarında anlaşamamaları, işlevsel ve etkin olmayan bir yapının kurulması, tüketici lehine zaman kaybı gibi riskler ön plana çıkmaktadır. Otoritenin düzenleme yapması halindeki en büyük risk ise, yapının ve sürecin işletilememesi durumudur.

Yaklaşım olasıııklarına göre yaşanabilecek bu başlıklar, bankacılıktaki hesap numarası taşınabilirliğinin değerlendirilmesi noktasında benzer çıkarımlar olarak görülebilir. Türkiye örneğinde, Bankacılık Düzenleme ve 
Denetleme Kurumunun (BDDK) ücret, komisyonlar ile ilgili yeni düzenlemesi devreye alınana kadar, tüketiciler birçok bankacılık ürün ve hizmetinde keyfi uygulamalar ile karşılaşmış ve finansal hizmetlere ulaşım imkânı ya da banka/hesap değişiminde ek maliyetlere (süre, açma/kapama, iki kere aynı maliyete tabii olma gibi) katlanmak durumunda kalmışlardır. Bu noktada, bankaların ilk dönemlerinde kendilerine tehdit olarak gördükleri "Fatura Ödeme Merkezleri (FÖM)" gerçeği Türkiye'de aslında bankacılık sektörünün karşılayamadığı bu durumlar nedeni ile doğmuştur. İlk zamanlarında, basında yer alan dolandırıcılık, kara para aklama ve benzer nedenler ile BDDK, Türkiye Bankalar Birliği (TBB) ve bankaların gündemine olumsuz olarak giren FÖM'ler, G-20 toplantılarında gündeme gelen ve üye ülke olarak Türkiye'nin de altına imza koyduğu “Finansal Tabana Yayılma" başlığı kapsamında, yasal düzenleme ile Temmuz 2013'den itibaren gerekli mevzuat şartlarının gerçekleşmesi şartı ile işlevsellik kazanmıştır. Benzer bir durum, piyasadaki "POS Tefeciliği" olarak yine örneklendirilebilir. BDDK'nın kredili mevduat hesaplarının ve kredi kartlarının faiz oranlarına bir üst bant getirmesi ve Türkiye Cumhuriyet Merkez Bankası tarafından belirlenen azami faiz oranlarının üstüne çıkılamaması durumuna kadar, bankalarca bu ürünlere uygulanan faiz oranlarının yüksekliği ve refinansman ihtiyaçları nedeni ile tüketicilerce yasal olmayan bu kurumlarca gidermek gerçeği ile sektörü ve ekonomiyi yüz yüze bırakmıştır. Ödeme sıkıntısına giren banka müşterileri, çalıştıkları bankalarda kredi geri ödemelerini yapılandıramadığı noktada, sanki ortada gerçek bir mal satışı varmış gibi, üye işyerlerinde kredi kartı ile yeni bir ödeme tablosu oluşturmakta, iskontolu olarak üye işyerinden aldıkları tutarlar ile mevcut kredilerini kapatmaktadırlar. Faiz marjlarının yüksek olması, bu anlamda bankalardan çok yasal olmayan kesimlere yaramakta ve tüketicinin aleyhine durumları daha çok doğurmaktadır. Bu sebeple, tüketici ve sektörün gelişimi lehine regülatörün yaptığı düzenlemelerin olumlu sonuçlarının, numara taşınabilirliğinin değerlendirilmesi noktasında dikkate alınması önemli bir kazanım olacaktır. Keza, operatörlerin kendilerinin inisiyatif alması olasılığına örnek olarak Türkiye'den yine bankacılık sektöründe Bankalararası Kart Merkezi (BKM) şirketi örneği verilebilir. Türkiye'deki bankaların kredi ve banka kartı takası, kart ve POS cihazının farklı bankalara ait olduğu not-on-us işlemlerin takası ve mutabakatı için kurdukları altyapı ve şirket, numara taşınabilirliği için hem örnek bir iş modeli, hem de bir değişim takas merkezi olasılığı olarak değerlendirilebilir. Olumsuz yönü ise, bankaların kendi inisayitifi ile kurduğu BKM'ye rağmen, Türkiye'de uzunca bir süre ATM'lerin ortak kullanıma açılamamasının ve Altın Nokta ve Ortak Nokta diye iki ayrı yapının var olmasının nihai tüketici için zorluklar ve ek maliyetler doğurması olarak görülebilir. Buradan en önemli çıkarım, Türkiye açısından banka hesaplarının taşınabilirliğinin gündeme gelmesi halinde, bunun kamu otoritesi koordinasyonda ve takibinde yürütülmesinin süreci olumlu ve hızlı yönde ve tüketici lehine daha fazla geliştireceği şeklinde bir öneri olarak görülmektedir. İnisiyatiflere son örnek olarak, bankaların kendi inisiyatifi ile TBB çalışma gruplarında kurduğu, 7 Haziran 2004 tarihi ile TBB tarafından duyurusu yapılan ancak filli uygulamada bankaların yürürlüğe alamadığı Doğrudan Borçlandırma Sistemi (Bankalararası Tahsilat Sistemi) örnek olarak verilebilir. (TBB, 2004)

TCMB'nin EFT sistemindeki sorgulama özelliğini kullanarak çalışması hedeflenen sistemde, müşterinin çalıştığı veya çalışmak istediği bankaya vereceği talimata istinaden, bir diğer çalıştığı bankadaki hesabına EFT aracılığı ile borç verilerek, talimatı alan bankadaki hesabına alacak geçilmesi işlemi olarak özetlenebilecek Doğrudan Borçlandırma Sistemi, bu özelliği ile genel olarak Numara Taşınabilirliği çalışmasına her bakımdan en yakın örnek olarak görünmektedir. TCMB EFT sistemi Türkiye'de 1 Nisan 1992 yılında hizmete girmiştir. 24 Nisan 2000 tarihinde EFT2 ile ikinci kuşak EFT Sistemine geçilmiş ve sistemde tek taraflı gönderim dışında var olan tek taraflı alacaklandırma imkânı işletim kurallarının uzlaşma ile belirlenememesi nedeniyle hayata geçememiştir. Hedeflenen "Doğrudan Borçlandırma Sistemi", 7 Haziran 2004 tarihinde 27 bankanın protokolü kendi inisiyatifleri ile Bankalar Birliği çatısı altında imzalaması ile yürürlüğe alınmıştır. Ancak ATM’lerin ortak kullanımında veya yabancı para cinsinden (dövize natık) düzenlenen çeklerin takasında olduğu gibi, çok şubeli bankaların başta müşteri kaybı ve rekabet gibi kaygıları nedeni ile sistem günlük hayatta uygulama bulamamıştır. Günümüzde halen, bankalar ancak kendilerinin ulaşabildiği ve kredi açmayı uygun gördüğü müşterilerle çalışabilmektedirler ve bayi, distribütör gibi listelerini kendileri ile paylaşıp alacak yönetimini kolaylaştırmak isteyen ana tedarikçi firmalara bekledikleri oranda hizmet seviyesini sağlamakta zorlanmaktadırlar. Bu nedenle, KOBi’lerin krediye ve finansal hizmetlere ulaşımındaki güçlükler kadar ana tedarikçi firmaların alacak ve risk yönetimi çalışmaları ve hizmet kalitesi, müşteri kapsama alanı, bankanın gelir imkânı olumsuz etkilenmekte, sistemde bütünsel bir kazanım gerçekleşmemektedir. Türkiye'den verilebilecek bu örnek, "Banka Hesap Numaralarının Taşınabilirliği" anlamında, regülatörlerin devrede olmasının gerekliliği 
üzerine de önemli bir sebep olarak gösterilebilir, ayrıca sektörde bir çalışmanın başlatılması halinde, yapılan bu çalışmalardan faydalanabilir.

Türkiye'de banka hesap numaralarının taşınmasına gerek var mıdır? Bu konuda, literatürdeki örneklere ve mevcut finansal hizmetlere ulaşımda yaşanan sıkıntılara bakıldığında, finansal ve teknolojik boyutu ayrıca incelenmek üzere, tüketiciler açısından sorunun cevabının açık bir şekilde evet çıkacağı beklenmelidir. Örneğin; maaş ödeme bankasını değiştiren bir şirketin çalışanları faturalarına ait otomatik ödemelerini eski bankasından yeni bankasına taşırken bütün fatura kurumları ile ve her iki banka ile tek tek uğraşmak zorunda kalmaktadır. Bu yüzden genelde hesaplarını eski bankada kapatmamakta ve fatura ödeme talimatlarını iptal etmemekte, maaşları yeni bankada hesaba yattığında, aynı gün EFT ile tekrar eski bankaya transfer edilerek fatura ödemeleri gerçekleştirilmektedir. Bu noktada, asında taraflar arasında kazanan bulunmamaktadır. Müşteri zaman ve işlem maliyetine katlanırken, maaşı ödemeye aracılık eden yeni bankanın çapraz satış rasyosu artmamakta, eski maaşın ödendiği bankada ise operasyon bankası olmaya devam edilmesi nedeni ile bir kazanç olmazken operasyonel maliyetler artmaktadır. İşlem maliyetlerine her üç tarafça katlanılmaya devam edilirken, bundan dolayı verim alamayan bankalar işlem maliyetlerini, hesap işletim ücreti gibi isimler altında müşterilerine yansıtmakta ve müşteriler daha çok mutsuzlaşırken, müşteri deneyimi de olumsuzlaşmaktadır. Ayrıca, analitik CRM çalışmaları kapsamında bankaların müşteri kayıp ve erime rasyolarının da, inaktif hesapların çokluğu nedeni ile realistik hesaplanamadığı, bu inaktif hesapların tasarruf bilincine ve makro raporlamalara olumsuz yansıdığı da ayrı bir durum saptaması olarak kayıtlara geçmektedir.

Tablo 1: Türkiye'deki Tasarruf Mevduat Adedi Gelişimi

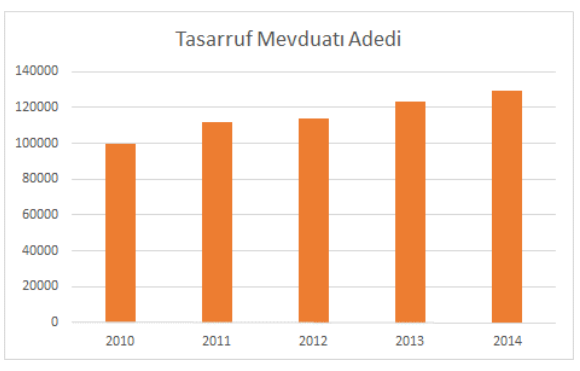

Kaynak: Türkiye Bankalar Birliği, Web Sitesi. Ana Sayfa, Banka ve Sektör Bilgileri, Veri Sorgulama Sistemi, illere ve Bölgelere Göre Bilgiler. http://www.tbb.org.tr/tr/banka-ve-sektor-bilgileri/veri-sorgulama-sistemi/illere-ve-bolgelere-gore-bilgiler/73 (Erişim Tarihi: 15.01.2016)

Bankacılıkta hesap numarası taşınabilirliği, aslında hizmet taşınması anlamında, Telekom'daki roaming (operatörler arası dolaşım) işlemlerine benzetilmektedir. ATM'lerde veya SWIFT MT940 mesaj tipinde hesap hareketi sorgulama ve gönderimi, not-on-us işlemler ile başka banka ATM ve POS'undan kart ile işlem yapma hizmet taşımasına örneklerdir. (Jain ve Kudidhi, 2015) Hindistan'da nüfusun yoğunluğu, banka ve şube sayılarının çokluğu dikkate alındığında, hesap numaralarının taşıma alternatifini kolaylaştırmak için yazılımın yeknesak hale getirilmesi üzerine akademik olarak yapılmış bir öneriye yine literatürde rastlanılmıştır. (Agarwal, 2013)

Banka Hesap Numarası Taşınabilirliği - BHNT (Bank Account Number Portability - BANP) üzerinde limitli ülke uygulamalarında ve literatürde tam bir uzlaşma bulunmamaktadır. Bu anlamda, bir kıyaslama yapılırsa, kredi kartlarında VISA ve MASTERCARD'ın dünya genelinde koyduğu işlem standartları gibi üzerinde uzlaşılmış ve bir takas, mutabakat ve switch sistemi bulunmamaktadır.

Tüm incelenen ülkelerde, şeffaflık, pazara giriş ve rekabet, tüketiciye yönelik kazanımlar, serbest piyasa ekonomisi, bankacılık sektörünün sürdürülebilir gelişimi gibi ana başlıklar üzerinden konunun tartışıldığı görülmekle beraber, Hollanda örneğinde olduğu gibi, banka hesaplarının taşınabilirliği noktasında, sistemi devreye alan ülkelerde hala tüketicilerin büyük bir yüzdesinin bu imkandan habersiz olduğu görülmüştür. Hollanda'da Monitor Financial Sector ve The Netherlands Authority for Consumers \& Markets adlarındaki kamuya ait alt çalışma organizasyonları, ilgili raporlarında (Beck, Bijlsma, Bikker ve Sinderen, 2014), Ekonomi 
Bakanlığınca yapının daha ileriye taşınması ve yaygınlaşması için başta Dutch Payments Association (Betaalvereniging Nederland) olmak üzere, konunun daha detaylı incelemesini tavsiye etmiştir. Buradan hareketle, Türkiye'de yapılacak bir çalışmanın varlığı halinde, en önemli başlıklardan birinin tüketicilerin/müşterilerin düzenli ve ulaşılabilir şekilde bilgilendirilmesi gerekliliğidir.

Son olarak, finansal hizmetlerin mobil ödemeler, mobil para transferleri, mobil sigorta uygulamaları ile dünyada mobilleştiği göz önüne alındığında, yukarıda sayılan diğer ülke örnekleri de dikkate alındığında, numara taşınabilirliğinin tüm taraflar için birçok açıdan fayda sağlayacağı savunulmaktadır.

\section{BULGULAR}

Dünyadaki örneklere ve uygulamanın benzeri diğer sektör kıyaslamalarına bakıldığında, banka hesaplarının taşınabilirliği teknik, süreç ve mevzuat olarak mümkün olmakla beraber, bu çalışmalara başlayacak olan ülkeler açısından işlemler o kadar basit olmayacaktır. Türkiye için de aşağıdaki ana başlıklarda ilerlenecek çok yol bulunmaktadır.

"Banka Hesap Numaralarının Taşınabilirliği” için izlenmesi gereken adımlar ve dikkate alınması gereken konular, aşağıdaki başlıklar dâhilinde özetlenmektedir.

Öncelikle, konu BDDK, TMCB gibi regülatörlerce mi, yoksa BKM örneğinde olduğu gibi bankaların kendi inisiyatifinde mi sürdürülecektir? Burada kamunun konuyu "Finansal Tüketicinin Korunması" kapsamında ele alması daha doğru olacaktır.

Taşımalarda tam, kısmi taşıma şeklinden hangisinin tercih edileceği, bunların takas, taşıma merkezinin neresi olacağı, sıfırdan mı kurulacağı yoksa TCMB EFT, TBB'ye bağı Kredi Kayıt Bürosu (KKB) veya BKM'nin Switch altyapılarının mı kullanılacağı netleştirilmelidir.

2/7/2009 tarih ve 27276 sayılı Resmi Gazete'de yayımlanarak yürürlüğe giren Numara Taşınabilirliği Yönetmeliği'ne dayanılarak hazırlanan "Numara Taşınabilirliği Uygulama Sürecine ilişkin Usul Ve Esaslar" dokümanında yer aldığı ve telekomda olduğu gibi, kanunen ve buna dayalı yönetmelikler ile banka hesap numaralarının taşınması ile ilgili başvuru ve diğer gerekli formlarının düzenlenmesi en önemli gereksinimlerden biridir.

Taşıma işlemlerinde sürecin nasıl başlayıp, ne zaman ve nasıl sonlanacă̆ı, yılda kaç kere taşınabileceği, kimlerin hangi aşamada sorumluluk ve yükümlülüklerinin bulunduğu tespit edilmeli ve mevzuatla netleştirilmelidir.

Hangi hesap türlerinin taşınabileceği, örneğin vadeli mevduat, kredi ve yatırım hesaplarının veya KOBi gibi tüzel hesapların taşımaya konu olup olmayacağı, müşteri hesaplarında bloke var ise bu işlemin yapılıp yapılamayacağı, hesaplardan ayrılan munzam ve zorunlu karşılıkların nasıl çalışacağı (2 haftada bir TCMB'ye ayrılan zorunlu karşılıklar açısından), taşıma işlemlerinden bir ücret alınıp alınmayacağı, hangi dağıtım kanallarından başvuru alınabileceği, geriye dönük stopaj, vergi, vb. yasal durumların oluşması halinde bunun yeni hesaptan veya müşterilerden nasıl tahsil edileceği gibi konuların karara bağlanması gerekmektedir.

Sermaye yeterliliği ve risk yönetimi açısından, fraud, sahtecilik, Know Your Customer (Müşterini Tanı), Kara Para Aklama ve Terörizmin Finansmanı gibi MASAK (Mali Suçlar) kapsamında mevzuatın nasıl etki edeceği ve uygulamada neler yapılacağı, mahkeme kararı ile haciz işlemlerinde veya veraset işlemlerinde hesap taşımanın nasıl etkilenebileceği ve bunların nasıl yönetileceği yine incelenmesi gereken konulardır.

Rekabet Kanunu ve Bankacılık Kanununda yer alan hususlar, kayıtların 10 yıl saklanması zorunluluğu ile müşteri bilgilerinin gizliliği hükümleri dâhilinde konunun irdelenmesi gerekmektedir.

Fatura ödeme talimatları, çek karnesi, kiralık kasa, kredi kartı, kredili mevduat hesabı, internet şube gibi hesaba bağı bankacılık işlem ve hizmetlerinin statüleri ayrıca incelenmelidir. Her ne kadar IBAN ile hesap numaralarına bir standart getirilse de, diğer bankada hesap numarası çakışmaları olasılığı göz ardı edilmemelidir. Özetle, bankacılığın birçok temel taşı ve detaylı işleyişinin incelenmesi gerekmektedir. 


\section{SONUÇ}

Mobil bir dünyada, tüketici davranışları ve tercihleri değişirken, bir bankadan diğer bir bankaya taşınmak durumunda kalınan fatura talimatları, kredi hesapları, vade sonunda başka bir bankada faiz oranı farkı nedeni ile açılan yeni birikim ve yatırım hesapları, aslında hizmet sektöründe müşteri odakılığı bu kadar ön plana çıkaran bankalar için mutlaka değerlendirilmesi gereken birer konu başlığıdır. Ayrıca, "Finansal Tüketicinin Korunması ve Finansal Hizmetlere Erişim" kapsamında kamunun önderliğinde yapılan çalışmaların önemli bir parçasını oluşturacak bir hizmet türü olarak görülmektedir.

Fakat bankacılıkta hesap numarası ve otomatik ödeme talimatlarının taşınabilirliğine öncelikle mevzuat açısından bakılması gerekmektedir. Bankacılık Kanunu'na göre "Bankacılık Sırrı” kapsamında müşteri bilgilerinin izinsiz paylaşımı suçtur. Ayrıca, MASAK dâhilinde kara para aklamanın, terörizmin finansmanının engellenmesi, bankaların müşterilerini tanıma (KYC- Know Your Customer) zorunluluğu bulunmaktadır. Yine mevzuat gereği bankacılıkta ve ticari hayatta kayıtların elektronik veya basılı olarak 10 yıl saklanma zorunluluğu bulunmaktadır. Böyle bir yapının hayata geçirilmek istenmesi durumunda, diğer önemli konular arasında hangi takas merkezi veya sisteminin kullanılacağı veya olacağı ya da hangi hesapların taşınabilir olabileceğinin de karara bağlanması gerekmektedir. Keza, tam veya kısmi taşıma, regülatör veya bankaların inisiyatifi ile mi sürecin işletileceği konuları da iş modellerinin netleştirilmesi açısından önemlidir. Tabii bunların dışında, teknolojik yapının nasıl kurulacağı, işlemlerde operasyonel risk yönetiminin nasıl yapılacağı ve hesaplanacağı, sermaye yeterlilik rasyosu dâhil, munzam karşılıklara olan etkisi gibi konular da önemlidir. Hesapların yıl içinde kaç kez taşınabileceği, fatura ödeme talimatları ve banka (debit) kartlarının nasıl etkileneceği gibi birçok başlığa daha bakılması gerekmektedir.

Banka müşterileri, zorunluluklar ve hesap işletim ücreti gibi finansal kaygılar nedeni ile farklı bankalar ile çalışmak durumunda kalabilmektedirler. Türkiye özelinde, cari açık ve enflasyon nedeni ile kaydi paranın kontrol edilmek istendiği bir dönemde, kredi kartları ve kredi limitlerinin kontrollü bir şekilde yönetilmesinin arzulandığı bir ortamda, kayıt dışı ekonominin kayıtlanmasına çalışılan bir yerde, hesap sahiplerince bile kontrol edilmekte zorlanılan hesap sayılarının numara taşınabilirliği ile azalması sayesinde birçok işlemin kolaylaşması ve operasyonel verimlilik mümkün olabilir.

Sonuç olarak, yukarıdaki paragraflarda özetlediğimiz bulgular ve tartışmalar göstermektedir ki, üyesi olmak için çalıştığımız Avrupa Birliği müktesebatına göre bankacılıkta numara taşıma işlemlerini yapmamız kaçınılmazdır. Bu çalışmamız, bundan sonraki benzer konu başlıklarına bir temel teşkil edecek ve detaylı analizler için Türkiye'deki ilk çalışma olarak ışık tutacaktır.

\section{KAYNAKÇA}

Agarwal, S. and Agarwal, A. (2013), Object Oriented Model for Bank Account Number Portability, International Journal of Conceptions on Computing and Information Technology, Vol. 1, Issue. 1, ISSN: 2345 - 9808

Beck, T. Bijlsma, M. Bikker, J. Sinderen, J. (2014), Barriers to Entry into The Dutch Retail Banking Sector, Monitor Financial Sector and The Netherlands Authority for Consumers \& Markets, p.83-84

BEUC (Bureau Européen des Unions de Consommateurs Aisbl), The European Consumer Organisation, Team Financial Services. (2012), Consultation on Bank Accounts Commission Services Working Paper BEUC response, Ref.: X/2012/042 - 12/06/2012, p.13-19

Bloomberght, Teknoloji. (2015), Cepte Numara Taşımada En Çok Hangi Operatör Müşteri Kaybetti? (31 Aralık 2015), http://www.businessht.com.tr/teknoloji/haber/1174668-cepte-numara-tasimada-en-cok-hangi-operator-musteri-kaybetti, (Erişim Tarihi: 15.01.2016)

cbanque.com. (2012), Cmobilité Bancaire: UFC-Que Choisir Réclame La Portabilité Du Numéro De Compte, http://www.cbanque.com/actu/29364/mobilite-bancaire-ufc-que-choisir-reclame-la-portabilite-du-numero-de-compte, Accueil > Actualité > Banque, (Erişim Tarihi: 15.01.2016)

Cho, D. Ferreira, P. and Telang, R. (2013), The Impact of Mobile Number Portability on Price, Competition and Consumer Welfare, SSRN: http://ssrn.com/abstract=2265104 veya http://dx.doi.org/10.2139/ssrn.2265104, (Erişim Tarihi: 15.01.2016)

Consumer International. (2012), World Consumer Rights Day 15 March 2012, Campaigning for a 'Real Choice' in Financial Services, p.4-5, http://www.consumersinternational.org/media/894988/wcrd\%202012\%20-

\%20member\%20briefing\%20on\%20competition\%20in\%20financial\%20services.pdf, (Erişim Tarihi: 15.01.2016) 
Doğan, Ç. (2005), Para Politikasının Etkinliği, Türkiye Açısından Bir Değerlendirilmesi (Effectiveness of Monetary Policy: Evaluation for Turkey), Süleyman Demirel Üniversitesi, İktisadi ve İdari Bilimler Fakültesi, Y.2005, C.10, S.1, p.26-27

Eyers, J. (2015), Banks Reject Call for Account Number Portability as Too Expensive, The Sydney Morning Herald, ttp://www.smh.com.au/business/banking-and-finance/banks-reject-call-for-account-number-portability-as-too-expensive-20150825gj7c17.htm, (Erişim Tarihi: 15.01.2016)

Fraser, B and Australian Government The Treasury. (2012), Competitive and Sustainable Banking System, Banking Services: Cost-effective Switching Arrangements, http://banking.treasury.gov.au/content/reports/switching or http://banking.treasury.gov.au/content/reports/switching/downloads/switchingarrangements_aug2011.pdf, (Erişim Tarihi: 15.01.2016)

Güngör, M. ve Evren, G. (Mart 2010), Mobil Numara Taşınabilirliği. Rekabete ve Tüketicilere Etkileri: Ardıl Düzenleyici Etki Analizi Çalışması, Ankara, Bilgi Teknolojileri ve İletişim Kurumu, Sektörel Araştırma ve Stratejiler Dairesi Başkanlığı, p.6-35

Jain, M. and Kudidhi, (2015), K. Bank Account Number Portability - A Perspective, p. 4. https://www.edgeverve.com/finacle/resources/thought-papers/Documents/bank-account-number-portability.pdf, (Erişim Tarihi: 15.01.2016)

Le Figaro. (2015), Mobilité Bancaire: La Simplifiation Notée, http://www.lefigaro.fr/flash-eco/2015/04/11/9700220150411FILWWW00060-mobilite-bancaire-le-senat-vote-la-simplification.php, (Erişim Tarihi: 15.01.2016)

Moorhouse Consulting. (2015), Account Number Portability, Report Commissioned by the Financial Conduct Authority, Published March 2015

Official Journal of the European Union, EUR-Lex. (2014), Directive on payment accounts - Factsheet 2 Switching payment accounts, http://ec.europa.eu/finance/finservices-retail/docs/inclusion/20130506-factsheet-2_en.pdf, (Erişim Tarihi: 15.01.2016)

Porter, M.E. (1985, republished 1998), Competitive Advantage: Creating and Sustaining Superior Performance,The Free Press, New York.

Que Choisir. (9 Aralık 2014), Mobilité Bancaire: Des Mythes à La Réalité, http://www.quechoisir.org/argent-assurance/banquecredit/service-bancaire/communique-mobilite-bancaire-des-mythes-a-la-realite-2-milliards-d-euros-de-pouvoir-d-achat-economisables,

(Erişim Tarihi: 15.01.2016)

Que Choisir. (2014), Mobilité Bancaire: Des Mythes à La Réalité, Direction des Études - Décembre 2014 http://image.quechoisir.org/var/ezflow_site/storage/original/application/7eb138f57161e33587d084721378f476.pdf, (Erişim Tarihi: 15.01.2016)

Resmî Gazete (5 Haziran 2014), Finansal Erişim, Finansal Eğitim, Finansal Tüketicinin Korunması Stratejisi ve Eylem Planları, 29021 Sayılı Genelge, 2014/10

Speyer, B. Schafer, S. (2007), Deutsche Bank Response to the Report of the Expert Group on" Customer Mobility in Relation to Bank Accounts, http://ec.europa.eu/internal_market/finservices-retail/docs/baeg/reply-corp-de-db_en.pdf, (Erişim Tarihi: 15.01.2016)

Tuğcu, C.T. (2015), Paranın Yansızlığı Hipotezinin Testi: Türkiye Ekonomisi İçin Yapısal Kırılmalı Eş Bütünleşme Analizi, İktisat Politikası Araştırmaları Dergisi, Journal of Economic Policy Researches, C.2, S.1, p.17-31

Türkiye Bankalar Birliği. (2004), Kamuoyuna Duyuru, https://www.tbb.org.tr/tr/ana-sayfa/onemli-basliklar/bankalararasi-tahsilatsistemi/296, (Erişim Tarihi: 15.01.2016) 